\title{
Social Phobia as a Predictor of Social Competence Perceived by Teenagers
}

\author{
Bünyamin Ateş ${ }^{1}$ \\ ${ }^{1}$ Faculty of Education, Erzincan University, Erzincan, Turkey \\ Correspondence: Bünyamin Ateş, Faculty of Education, Erzincan University, Erzincan, 24000, Turkey. Tel: \\ 90-0446-2240-0894-2152. E-mail: Bunyaminates81@gmail.com
}

Received: January 12, 2016 Accepted: February 13, 2016 Online Published: March 27, 2016

doi:10.5539/ies.v9n4p77

URL: http://dx.doi.org/10.5539/ies.v9n4p77

\begin{abstract}
In this research, it was analyzed to what extent the variables of social avoidance, concern for being criticized and sense of individual worthlessness as sub-dimensions of social phobia predicted the perceived social competence levels of teenagers. The study group of this study included totally 648 students including 301 (46.5\%) female and 347 (53.5\%) male studying at high-school grade in Erzincan Provincial center. Age interval of the research group varied between 14 and 18. In the research, Perceived Social Competence Scale, Social Anxiety Scale and Personal Information Form were used as data collection tools. The data obtained in the research were analyzed through the stepwise regression analysis method as one of the multiple linear regression analysis. According to the research findings, the variables of social avoidance, concern for being criticized and sense of individual worthlessness significantly predicted perceived social competence.
\end{abstract}

Keywords: perceived social competence, social phobia, teenager

\section{Introduction}

Since humankind has existed in the world, coexistence need of people has turned them into a social being. However, human's maintaining their social existence has forced them to have some social competences. At this point, the concept of social competence has become prominent as a factor affecting social and mental life of human. The concept of social competence has attracted several researchers since the past until today, and this concept has been tried to be defined by various researchers.

Upon this, Ford (1982) defined social competence as the strength for coping with encountered difficulties, and fulfilling specific social targets. Rose-Krasnor (1997) defined social competence as effectiveness in social interaction. In another definition, social competence was defined as individuals' potential of using existent social-communication skills (Sarıçam, A. Akın, U. Akın, \& Çardak, 2013). Furthermore, it was also noticed in the literature that social competence was defined as individuals' using their social skills efficiently during a social interaction or communication (Magelinskaite, Kepalaite, \& Legkauskas, 2014).

The concept of social competence can be noticed to be related with concepts such as self-sufficiency and social skill. In this sense, self-sufficiency is a concept related to how individuals perceive their own competences (Koç, 2009). Self-sufficiency is belief, decisiveness and effort of individuals upon achieving a task or behavior successfully (Erözkan, 2013). The concept of social skill considered to be in relation with the concept of social competence has been noticed to be used together with the concept of social competence and no clear distinction is possible to be made (Bacanl, 2012). However, social skill is the performance of individuals at starting, maintaining and ending point of a specific social task. And social competence includes judgment, belief and assessment related to the performance at a social task (Gresham, Sugai, \& Horner, 2001).

Social competence is a vital and necessary skill for individuals to struggle with difficulties, to maintain social relationships positively, to participate in community and group activities actively, and to be independent and active (Gedviliene, 2014). Social competence provides individuals to feel themselves more secure in interpersonal interactions, to be more productive, and therefore, to perceive and assess themselves more competent in interpersonal relationships (Erözkan, 2013). Social competence is an organized structure depending upon specific situations, purposes, processes and actions. Social competence perceptions of individuals mainly included viewpoints of both themselves and the others (Rose-Krasnor, 1997). Social competence is the result of 
past experiences, soul-searching, and interpersonal and social assessment (Coleman, 2003; Ten-Dam, \& Volman, 2007).

The factors such as evaluation, task, criteria, age, gender, role, status, culture, etc. are efficient upon social competence standards (Ford, 1982; Torres, Cardelle-Elawar, Mena, \& Sanchez, 2003; Rose-Krasnor, 1997). There are different approaches for explaining and measuring the social competence, and these four are generally preferred to be used: Social skills, socio-metric status, relationships, and functional outcomes (Rose-Krasnor, 1997). The main components of social competence are cooperation, politeness, candidness, dynamism, dominance, fussiness, ambition, friendship, interpersonal communication skills, fellowship, group acceptance, dependence, interest, assertiveness skills, trust, emotional control, impulse control and extroversion (Lianos, 2015; Rose-Krasnor, 1997; Torres, Cardelle-Elawar, Mena, \& Sanchez, 2003; Zsolnai, 2002). Social competence is a multi-dimensional structure. Social competence includes social, cognitive, affective and personal dimensions that are in an interaction with each other (Ford, 1982; Lianos, 2015; Márquez, Martín, \& Brackett, 2006; Ferris, Perrewé, \& Douglas, 2002).

When the literature related to the social competence was analyzed, it was noticed that as the level of social competence increased, loneliness (Zhang et al., 2014), behavioral problems and shyness (Chen et al., 2014), school anxiety (Magelinskaitè, Kepalaite, \& Legkauskas, 2014), negative automatic thoughts (Karahan, Sardoğan, Özkamalı, \& Menteş, 2006) and depression (Payne \& Jahoda, 2004) decreased; academic success (Green, Forehand, Beck, \& Vosk,1980), positive peer relationships (Coleman, 2003), empathy, conflict resolution skills and qualified friendship relationships (Chow, Ruhl, \& Buhrmester, 2013), social problem solving skills (Sumi, 2011), cognitive flexibility (Çelikkaleli, 2014) increased. Moreover, intrafamilial positive relationships (Lin \& Yawkey, 2014), social support perceived from friends and teachers (Kaş1k, 2009) were determined to be affecting the perception of social competence positively.

As could be understood from these research results, different variables were noticed to be efficient upon social competence perceptions of individuals. Apart from these variables, the problem of social phobia as a mental state affecting social competence perceptions, social relationships, and emotional health of individuals negatively was remarkable. In DSM-5, social phobia was defined as individuals' feeling a specific fear or anxiety in one or more than one social situations in which they will be evaluated by the others. Experienced social phobia causes individuals have loss of functionality in social, professional and other areas (DSM-5, 2014).

The social phobia has physiologic indicators (blush, dizziness, difficulty in breathing), cognitive indicators (feeling of inadequacy and dissatisfaction towards the self), emotional indicators (being afraid of participating into talking or being the side who starts talking), and behavioral indicators (avoiding from social environments, meeting new people, refraining from authority) (Kearney, 2005; Kuzucu, 2013). Social phobia has a structure including three factors. These are called as (1) social avoidance, (2) concern for being criticized, and (3) sense of individual worthlessness (Özbay \& Palanc1, 2001). Social phobia is associated with different factors, and has a negative effect upon life of individuals (Hamarta, 2015; Hampel, Weis, Hiller, \& Witthöft, 2011; Kircanski, Joormann, \& Gotlib, 2015; Türe, 2009; Raffray, Bond, \& Pelissolo, 2011; Richards et al., 2015). The individuals experiencing high level of social phobia (social avoidance, concern for being criticized and sense of individual worthlessness ) have been determined to have lower level of social competence perceptions, feel themselves under a social threat, and have lower expectations and social competence perceptions related to coping with social situations (Kashdan \& Roberts, 2004).

The social competence perception and relevant social phobia has significant effects upon the life of individuals at any stage of life; and moreover, these effects are especially more prominent in adolescence period. Because the importance and value of social environment and the relationships established with this social environment increases in this period. During this period, the teenager will be in struggle for making its existence felt individually within the society. In this sense, social competence perception of the teenagers is an important skill in terms of mental health and developing healthy relationships with their social environments including most their friends and teachers. At this point, it could be considered that determining the variables predicting perceived social competence levels of teenagers will be important and beneficial in terms of protective mental health.

In reference to this information, in this research answer was sought to the question of "Do the variables of social avoidance, concern for being criticized and sense of individual worthlessness as sub-dimensions of social phobia significantly predict perceived social competence levels of teenagers?" Depending upon this problem sentence, sub-problems of the study included these: a) To what extent do the variables of social avoidance, concern for being criticized and sense of individual worthlessness predict perceived social competences of teenagers together? 
b) How strong is each of these variables to predict perceived social competence levels of teenagers? c) What is the importance order of these variables for predicting the perceived social competence?

\section{Method}

\subsection{Research Model}

This research was a descriptive study on screening model related to analyzing to what extent the variables of social avoidance, concern for being criticized and sense of individual worthlessness as sub-dimensions of social phobia predicted the perceived social competence levels of teenagers.

\subsection{Research Group}

The study group of this study included totally 648 students including 301 (46.5\%) female and 347 (53.5\%) male studying at high-school grade in Erzincan provincial center. The age interval of the study group varied between 14 and 18.

\subsection{Data Collection Tools}

\subsubsection{Perceived Social Competence Scale}

The scale was developed by Anderson-Butcher, Iachini, and Amorose (2007), and adapted into Turkish culture by Sarıçam, A. Akın, U. Akın, and Çardak (2013). It was noticed in confirmatory factor analysis performed for the structural validity of the Perceived Social Competence Scale that the scale included 6 items in coherent with the original form and the items were mono-dimensional $\left(\mathrm{x}^{2}=7.34, \mathrm{SD}=7, \mathrm{RMSEA}=.010, \mathrm{CFI}=1.00, \mathrm{RFI}=0.99\right.$, $\mathrm{IFI}=1.00, \mathrm{AGFI}=.98, \mathrm{GFI}=.99, \mathrm{NFI}=.99$ and $\mathrm{SRMR}=.018$ ). Factor loads of the scale ranged from .57 and .80 . Cronbach alpha internal consistency coefficient was found as .80. Moreover, corrected item-total correlations of the scale were determined to be ranged between .52 and .66. In this study, Cronbach Alpha reliability coefficient for all the scale was determined to be .81 .

\subsubsection{Social Anxiety Scale (SAS)}

The scale was developed by Özbay-Palancı (2001). The scale includes three factors as (1) social avoidance, (2) concern for being criticized, and (3) sense of individual worthlessness. Positive linear relationships were found for MMPI Si sub-test $(\mathrm{r}=.43, p<001)$ used for the criteria validity of the test and sub-tests of sensitivity in interpersonal relationships $(\mathrm{r}=.51, p<.001)$, anxiety test $(\mathrm{r}=.25, p<.01)$, phobic anxiety $(\mathrm{r}=.36, p<.001)$, depression $(\mathrm{r}=.40, p<.001)$. Availability of the coherence related to the distribution was analyzed through reliability calculations. As result of the variance analysis, the result was found as significant at the level of $\mathrm{F}=68.58, p<.001$. Cronbach Alpha value calculated with internal consistency method for the reliability calculations was .89. The test had Likert type five-point grading at 0-4 interval. The increase at obtained scores proved the increase at SA level (Özbay-Palanc1, 2001). In this study, Cronbach Alpha reliability coefficient of the scale was determined to be 0.85 .

\subsubsection{Personal Information Form}

The form was developed by the researcher in order to obtain personal information of the students creating the study group within the scope of the research.

\subsection{Collection of Data}

The data collection tools used in the research were performed to the students in groups by the researcher. Before performing the data collection tools to the groups, information related to the purpose of the research was provided. Volunteering of the students was essential for collecting the data. Implementations were maintained for nearly 45 minutes in each group.

\subsection{Data Analysis}

In the research, normality and linearity of the data sets were primarily evaluated in order to determine whether the data were appropriate for the multiple linear regression analysis or not. Whether there were extreme values that complicated normality (multi-variable) and linearity assumptions was analyzed according to Mahalanobis distance (16.27), Cook's $\left(\right.$ Cook' $\left.^{\prime} 1\right)$ and Leverage Values (.000-.020). Additionally, kurtosis, skewness values and scatter and histogram graphics of data sets were also analyzed. The data of 21 participants were excluded from the data set because they had extreme values at a level affecting the data analysis. Beside data sets' providing linearity and normality conditions, sample size was also noticed to be at an adequate number when the number of variable was considered. Because finding no high correlation coefficient between the predictive variables as another assumption of multiple regression analysis, zero-order correlation coefficients, tolerance value, VIF and CI values were analyzed. It was determined that there was no correlation value over .80 possible 
to be defined as multiple correlation between the predictive variables (Table 1), tolerance value was over .20, VIF value was lower than 10, and CI value was lower than 30. Finally, Durbin-Watson value was analyzed in order to analyze independence of errors; and the value was noticed to be between 1 and 3 (DW=1.84), and comprised no problem.

Depending on these processes, obtained data were noticed to be appropriate for multiple linear regression analysis. The data obtained in the research were analyzed with stepwise regression analysis method as one of the multiple linear regression analysis. In the research, .05 level of significance was regarded (Akbulut, 2010; Büyüköztürk, 2011; Seçer, 2013).

\section{Findings}

In this section, the relationships between the predicted variable (Perceived Social Competence) and the predictive variables (Social Avoidance, Concern for Being Criticized and Sense of Individual Worthlessness) were primarily analyzed (Table 1). Subsequently, stepwise regression analysis as one of the multiple linear regression analysis methods was performed, and the results were presented in Table 2.

Table 1. Correlation coefficients related to perceived social competence, social avoidance, concern for being criticized, and sense of individual worthlessness

\begin{tabular}{lcccc}
\hline & P.S.C. & S.A. & C.B.C. & S.I.W. \\
\hline P.S.C. & 1 & & & \\
\hline S.A. & $-.498^{* *}$ & 1 & & \\
\hline C.B.C. & $-.549 * *$ & $.695^{* *}$ & 1 & \\
\hline S.I.W. & $-.559^{* *}$ & $.590^{* *}$ & $.744^{* *}$ & 1 \\
\hline
\end{tabular}

$* * \mathrm{P}<.01$, P.S.C. (Perceived Social Competence), S.A. (Social Avoidance), C.B.C. (Concern for Being Criticized), S.I.W. (Sense of Individual Worthlessness).

When Table 1 was analyzed, it was noticed that there was negative significant relationships between perceived social competence and social avoidance, concern for being criticized and sense of individual worthlessness.

When ANOVA table that tested the relationship of predictive variables related to stepwise regression analysis with the predicted variable, and the significance of predictive variables' explaining the change in the predicted variable was analyzed, explained variance or regression model was determined to be statistically significant $(\mathrm{p}<.01)$. F values related to ANOVA table were presented in Table $2\left(\mathrm{~F}_{1 / 646}=293.16 ; \mathrm{F}_{2 / 645}=177.96 ; \mathrm{F}_{3 / 644}=125.46\right.$; $\mathrm{p}<.01)$. According to this, predicting variables successfully achieved prediction process upon the model.

When Table 2 was analyzed, because stepwise regression analysis significantly predicted perceived social competence, the variables of "SA," "CBC," and "SIW" were determined to be processed during the stepwise regression analysis process. When both beta values and partial and zero-order correlation coefficients were analyzed, it was noticed that there was a negative significant relationship between the variable of social competence and the variables of "SA," "CBC," and "SIW." The variables of "SA," "CBC," and "SIW" explained approximately $37 \%$ of the total variance related to social competence $\left(\mathrm{R}=.607 ; \mathrm{R}^{2}=.369 ; \mathrm{P}<.01\right)$. 
Table 2. Stepwise multiple regression analysis results related to prediction of perceived social competence

\begin{tabular}{|c|c|c|c|c|c|c|c|c|c|c|}
\hline Model & & C. & S. C. & & Correla & ions & & & & \\
\hline & $B$ & $\begin{array}{c}\text { Std. } \\
\text { Error }\end{array}$ & Beta & $\mathrm{t}$ & $\begin{array}{c}\text { Zero-Or } \\
\text { der }\end{array}$ & Partial & $\mathrm{R}$ & $\mathrm{R}^{2}$ & $\mathrm{~F}$ & $\mathrm{df}$ \\
\hline $1^{\text {st }}($ Constant $)$ & 30.80 & .651 & & $47.35^{* *}$ & & & \multirow[b]{2}{*}{$.559^{\mathrm{a}}$} & \multirow[b]{2}{*}{.312} & \multirow[b]{2}{*}{$293.16^{* *}$} & \multirow[b]{2}{*}{$1 / 646$} \\
\hline S.I.W. & -.492 & .029 & -.559 & $-17.12 * *$ & -.559 & -.559 & & & & \\
\hline $2^{\text {nd }}$ (Constant) & 32.21 & .666 & & $48.40 * *$ & & & \multirow{3}{*}{$.596^{\mathrm{b}}$} & \multirow{3}{*}{.356} & \multirow{3}{*}{$177.96^{* *}$} & \multirow{3}{*}{$2 / 645$} \\
\hline S.I.W. & -.358 & .034 & -.407 & $-10.38 * *$ & -.559 & -.379 & & & & \\
\hline S.A. & -.174 & .026 & -.258 & $-6.59 * *$ & -.498 & -.251 & & & & \\
\hline $3^{\text {rd }}$ (Constant) & 32.15 & .659 & & $48.77 * *$ & & & \multirow{4}{*}{$.607^{\mathrm{c}}$} & \multirow{4}{*}{.369} & \multirow{4}{*}{$125.46^{* *}$} & \multirow{4}{*}{$3 / 644$} \\
\hline S.I.W. & -.270 & .042 & -.306 & $-6.46^{* *}$ & -.559 & -.247 & & & & \\
\hline S.A. & -.122 & .030 & -.181 & $-4.11 * *$ & -.498 & -.160 & & & & \\
\hline C.B.C & -.133 & .036 & -.196 & $-3.68 * *$ & -.549 & -.144 & & & & \\
\hline
\end{tabular}

$* * \mathrm{P}<.01$ U. C. (Unstandardized Coefficients), S. C. (Standardized Coefficients).

Beta coefficient of "SIW" variable analyzed in the first step of stepwise regression analysis was ,-559 in predicting the social competences. T-test results related to significance of Beta coefficient was found as significant $(\mathrm{t}=-17.12 ; \mathrm{P}<.01)$. The variable of "SIW" solely explained approximately $31 \%$ of perceived social competences of teenagers $\left(\mathrm{R}=.559 ; \mathrm{R}^{2}=.312\right)$.

In the second step of stepwise regression analysis, "SA" variable was added to "SIW" variable in the model. When the other variables that affected perceived social competence were kept as constant, the variables of "SIW" and "SA" together explained approximately $36 \%$ of perceived social competence $\left(\mathrm{R}=.596 ; \mathrm{R}^{2}=.356\right)$. When the other variables in the model were kept as constant, Beta coefficient of "SIW" variable was -.407; and Beta coefficient of "SA" variable was -.258. T-test results related to the significance of Beta coefficient was determined as significant $\left(\mathrm{t}_{\mathrm{SIW}}=-10.38 ; \mathrm{P}<.01 / \mathrm{t}_{\mathrm{SA}}=-6.59 ; \mathrm{P}<.01\right)$.

In the third step of stepwise regression analysis, "CBC" variable was also added to the "SIW" and "SA" variables in the model. When the other variables affecting perceived social competence were kept as constant, "SIW," "SA," and "CBC" variables together explained approximately " $37 \%$ of perceived social competence $\left(\mathrm{R}=.607 ; \mathrm{R}^{2}=.369\right)$. When the other variables in the model were kept as constant, Beta coefficient of "SIW" was -.306; Beta coefficient of "SA" variable was -.181, and Beta coefficient of "CBC" variable was -.196. T-test results related to the significance of Beta coefficient was found as significant $\left(\mathrm{t}_{\mathrm{SIW}}=-6.46 ; \mathrm{P}<.01 / \mathrm{t}_{\mathrm{SA}}=-4.11\right.$; $\left.\mathrm{P}<.01 / \mathrm{t}_{\mathrm{CBC}}=-3.68 ; \mathrm{P}<.01\right)$.

According to t-test results related to the significance of Beta coefficients and Beta coefficients included into the model in the third step, the variables of SIW, SA and CBC were determined to significantly predict perceived social competence. When Beta values related to the variables in the model were considered, perceived social competences of teenagers were significantly predicted by "SIW" in the first rank, by "CBC" in the second rank, and by "SA" in the third rank. In other words, relative importance order of predictive variables upon perceived social competence was as "SIW," "CBC," and "SA."

\section{Conclusion, Discussion and Suggestions}

At the end of the study, it was found that there were negative significant relationships between perceived social competences of teenagers and social avoidance, concern for being criticized and sense of individual worthlessness. Furthermore, the variables of social avoidance, concern for being criticized and sense of individual worthlessness were determined to be significant predictors of perceived social competence variable. These three variables together explained approximately $37 \%$ of the perceived social competence. Perceived social competences of teenagers were significantly predicted by "SIW" in the first rank, by "CBC" in the second rank, and by "SA" in the third rank.

When the results above were considered, all sub-dimensions of social phobia as social avoidance, concern for being criticized and sense of individual worthlessness were noticed to be significant predictors of perceived social competence in teenagers. In this sense, one way of increasing social competence perceptions in teenagers 
is mentioned to be possible through decreasing their social phobia levels. Social competence skill emerging as an important skill for human as a social existence to take a place in the society is essential at every stage of life, and becomes especially more significant during the adolescence period. Because quality and efficiency level of the relationship established with the social surrounding not only affects social relationships of teenagers who lean to social surrounding more rather than the family but their mental health, as well. Teenagers' perceiving themselves competent in their social relationships can contribute upon their establishing more qualified, efficient and healthy relationships. In this sense, determining the factors possible to affect the social competence perceptions of teenagers and protective mental health studies to be carried out in this framework is considered to be important.

Within the scope of this study, it was possible to mention that the teenagers with low level of perceived social competence could experience social phobic symptoms such as feeling worthlessness, dissatisfaction with the self, not accepting criticism and personal traits, being afraid of behaving wrongly, and avoiding from establishing social relationship and communication at high levels. In other words, because teenagers with high social phobia felt themselves under threat socially, they were considered to have lower social competence perceptions related to feeling themselves secure in social relationships, coping with social problems, and being an active member of the society.

According to the results obtained in this research, it was determined that sense of individual worthlessness variable significantly predicted perceived social competence of teenagers at the first rank, and there was a negative significant relationship between the variables. In the relevant literature, perceived social competence was noticed to be discussed and analyzed with different variables (Boling, Barry, Kotchick, \& Lowry, 2011; Castedo, Juste, \& Alonso, 2015; Chow, Ruhl, \& Buhrmester, 2013; Çelikkaleli, 2014; Erözkan, 2013; Lianos, 2015; Traş \& Arslan, 2013). However, the studies in which perceived social competence and sense of individual worthlessness as a sub-dimension of social phobia were discussed and analyzed together has been fairly limited (Kashdan \& Roberts, 2004). Sense of individual worthlessness reflects contents such as feeling self as worthless, dissatisfaction with the self, not accepting help from the others, failure identity, and not accepting criticism and personal traits (Özbay \& Palanc1, 2001). Such feelings can negatively affect self-confidence, belief, and social competence perception level of teenagers in social interactions and communications. And this negatively affects social relationships and mental health. At this point, increasing social competence perception levels of teenagers, decreasing their sense of individual worthlessness and providing them to feel as a valuable member of the society have been considered to be essential in terms of mental health.

In this study, it was determined that the variable of concern for being criticized significantly predicted perceived social competence of teenagers at the second rank, and there was a negative significant relationship between the variables. In the literature, it was noticed that both concern for being criticized as sub-dimension of social phobia and perceived social competence variables were discussed and analyzed together with different variables. In previous studies, it was determined that high level of social phobia (concern for being criticized) negatively affected life of individuals, and high level of perceived social competence created a positive effect upon individuals (Connolly, 1989; Baltacı \& Hamarta, 2013; Erözkan, 2011; Márquez, Martín, \& Brackett, 2006). Furthermore, because the individuals with high level of concern for being criticized as the most important indicator and sub-dimension of social phobia felt themselves under threat socially, they were noticed to have low competence perceptions related to coping with social problems (Usher, Burrows, Schwartz, \& Henderson, 2015; Thomasson \& Psouni, 2010).

The concern for being criticized is a factor including worries such as the redundancy of self-control efforts, and fear for being rejected and humiliated (Özbay \& Palanc1, 2001). Teenagers with such concerns act by the thought of making mistakes while fulfilling a social process. It has also been considered that self-perception and belief of teenagers with the concern for being criticized and making mistakes in their social interaction and communications are possible to be affected negatively from this. In this sense, high level concern for being criticized is possible to be mentioned as decreasing perceived social competence levels of teenagers. Therefore, teenagers' level of being criticized can be decreased in order to increase perceived social competence levels of teenagers.

In the research, it was determined that the variable of social avoidance significantly predicted perceived social competence of teenagers at the third rank, and there was a negative significant relationship between the variables. It was noticed in the relevant literature that high level of perceived social competence level created positive effects upon the individuals; however, social phobia and social avoidance as an important sub-dimension of social phobia had negative effects (Connolly, 1989; Güneş \& Traş, 2013; Kircanski, Joormann, \& Gotlib, 2015; Malik \& Shujja, 2013; Sumi, 2011; Türe, 2009). 
Social avoidance includes various situations and symptoms possible to be discussed within the scope of social phobia such as avoiding from social relationships, reluctance for establishing communication, anxiety towards social interaction, speech impediment, and experiencing fear for going into the crowd and authority anxiety (Özbay \& Palanc1, 2001). Avoidance of teenagers experiencing such problems from social environments and interactions can negatively affect their social competence perceptions. That is to say, if teenagers are continuously trying to avoid from social environments and reflects situational social phobic symptoms, this will negatively affect their belief, thought and perception related to their being efficient in social environments. In other words, the social competence perceptions of teenagers who experience social phobia before or during the social relationship and communication and, therefore, avoid from such environments are possible to be affected negatively from this. In this sense, social avoidance can be mentioned as one of the factors affecting social competence perceived at low level in teenagers.

Finally, perceived social competence level not only affects social relationships of teenagers but also their mental health; and decreasing sense of individual worthlessness, social avoidance and concern for being criticized will be efficient upon increasing perceived social competence levels of teenagers. These suggestions were offered as result of this study:

- The research group of this study included teenagers studying at high school grade in Erzincan Provincial center. Such a study can also be carried out with different research groups such as the ones who are not maintaining their educational process.

- In this study, sub-dimensions of social phobia were discussed as the predictor of perceived social competences. Different variables that can also predict perceived social competences of teenagers are also possible to be analyzed.

- At the end of this study, it was determined that sense of individual worthlessness, social avoidance and concern for being criticized as sub-dimensions of social phobia significantly predicted perceived social competences of teenagers. At this point, further studies (seminar, conference, psycho-educational group therapies, psychological counseling support, peer groups, etc.) can be carried out related to decreasing sense of individual worthlessness, social avoidance and concern for being criticized in teenagers, increasing their social competence perceptions.

- On this subjects, similar studies can be carried out towards families, teachers, etc. who have direct or indirect effects upon teenagers.

\section{References}

Akbulut, Y. (2010). Sosyal bilimlerde SPSS uygulamaları. İstanbul: İdeal Kültür Yayıncılık.

Amerikan Psikiyatri Birliği.(2014). Ruhsal bozuklukların tanısal ve sayımsal elkitabı (5. Baskı). (DSM-5), tanı ölçütleri başvuru elkitabı'ndan (Çev. E. Köroğlu). Ankara: Hekimler Yayın Birliği.

Bacanl1, H. (2012). Sosyal beceri eğitimi (4. Baskı). Ankara: Pegem Akademi Yayınc1lık.

Baltacı, Ö., \& Hamarta, E. (2013). Üniversite öğrencilerinin sosyal kaygı, sosyal destek ve problem çözme yaklaşımları arasındaki ilişkinin incelenmesi. Eğitim ve Bilim, 38(167), 226-240.

Boling, M. W., Barry, C. M., Kotchick, B. A., \& Lowry, J. (2011). Relations among early adolescents' parent-adolescent attachment, perceived social competence, and friendship quality. Psychological Reports, 109(6), 819-841. http://dx.doi.org/10.2466/02.07.09.21.PR0.109.6.819-841

Büyüköztürk, Ş. (2011). Sosyal bilimler için veri analizi el kitabı (15. Baskı). Ankara: Pegem Akademi Yayıncılık.

Castedo, A. L., Juste, M. P., \& Alonso, J. D. (2015). Social competence: Evaluation of assertiveness in Spanish adolescents. Psychological Reports, 116(1), 219-229. http://dx.doi.org/10.2466/21.PR0.116k12w5

Çelikkaleli, Ö. (2014). Ergenlerde bilişsel esneklik ile akademik, sosyal ve duygusal yetkinlik inançları arasındaki ilişki. Eğitim ve Bilim, 39(176), 347-354.

Chen, X., Zhang, G., Liang, Z., Zhao, S., Way, N., Yoshikawa, H., \& Deng, H. (2014). Relations of behavioural inhibition with shyness and social competence in Chinese children: Moderating effects of maternal parenting. Infant and Child Development, 23(3), 343-352. http://dx.doi.org/10.1002/icd.1852

Chow, C. M., Ruhl, H., \& Buhrmester, D. (2013). The mediating role of interpersonal competence between adolescents' empathy and friendship quality: A dyadic approach. Journal of Adolescence, 36(1), 191-200. http://dx.doi.org/10.1016/j.adolescence.2012.10.004 
Coleman, P. K. (2003). Perceptions of parent-child attachment, social self-efficacy and peer relationships in middle childhood. Infant and Child Development, 12, 351-368. http://dx.doi.org/10.1002/icd.316

Connolly, J. (1989). Social self-efficacy in adolescence: Relations with self-concept, social adjustment, and mental health. Canadian Journal of Behavioural Science, 21(3), 258-269. http://dx.doi.org/10.1037/h0079809

Erözkan, A. (2011). Kaygı duyarlığı ve sosyal kaygının depresyon üzerindeki yordayıcı rolü. Journal of New World Sciences Academy, 6(1), 1119-1128.

Erözkan, A. (2013). İletişim becerileri ve kişilerarası problem çözme becerilerinin sosyal yetkinliğe etkisi. Kuram ve Uygulamada Ĕ̈itim Bilimleri, 13(2), 731-745.

Ferris, G. R., Perrewé, P. L., \& Douglas, C. (2002). Social effectiveness in organizations: Construct validity and research directions. Journal of Leadership \& Organizational Studies, 9(1), 49-63. http://dx.doi.org/10.1177/107179190200900104

Ford, M. E. (1982). Social cognition and social competence in adolescence. Developmental Psychology, 18(3), 323-340. http://dx.doi.org/10.1037/0012-1649.18.3.323

Gedviliene, G. (2014). The case of Lithuanıa and Belgium: Teachers and students' social competence. European Scientific Journal, 10(13), 181-294.

Green, K. D., Forehand, R., Beck, S. J., \& Vosk, B. (1980). An assessment of the relationship among measures of children's social competence and children's academic achievement. Child Development, 51(4), 1149-1156. http://dx.doi.org/10.2307/1129556

Gresham, F. M., Sugai, G., \& Horner, R. H. (2001). Interpreting outcomes of social skills training for students with high-incidence disabilities. Exceptional children, 67(3), 331-344.

Güneş, F., \& Traş, Z., (2013). Üniversite öğrencilerinin sosyal problem çözme düzeylerinin sosyal yetkinlik açısından incelenmesi. The Journal of Academic Social Science Studies, 6(7), 1099-1108.

Hamarta, E. (2015). Ergenlerde sosyal kaygının stresle başa çıkma yaklaşımlarına göre incelenmesi. Eğitim ve Bilim, 40 (180), 125-134.

Hampel, S., Weis, S., Hiller, W., \& Witthöft, M. (2011). The relations between social anxiety and social intelligence: A latent variable analysis. Journal of Anxiety Disorders, 25(4), 545-553. http://dx.doi.org/10.1016/j.janxdis.2011.01.001

Karahan, T. F., Sardoğan, M. E., Özkamalı, E., \& Menteş, Ö. (2006). Lise öğrencilerinde sosyal yetkinlik beklentisi ve otomatik düşüncelerin, yaşanılan sosyal birim ve cinsiyet açısından incelenmesi. Türk Psikolojik Danışma ve Rehberlik Dergisi, 3(26), 35-45.

Kashdan, T. B., \& Roberts, J. E. (2004). Social anxiety's impact on affect, curiosity, and social self-efficacy during a high self-focus social threat situation. Cognitive Therapy and Research, 28(1), 119-141. http://dx.doi.org/10.1023/B:COTR.0000016934.20981.68

Kaşı, D. Z. (2009). Ergenlerde karar verme stilleri ve algllanan sosyal destek düzeylerinin sosyal yetkinlik beklentisi ve bazı değişkenler açısından incelenmesi (Yüksek lisans tezi). Selçuk Üniversitesi Sosyal Bilimler Enstitüsü, Konya.

Kearney, C. A. (2005). Social anxiety and social phobia in youth. USA: Springer Science and Business Media İnc.

Kircanski, K., Joormann, J., \& Gotlib, I. H. (2015). Attention to emotional information in social anxiety disorder with and without co-occurring depression. Cognitive Therapy and Research, 39(2), 153-161. http://dx.doi.org/10.1007/s10608-014-9643-7

Koç, G. (2009). Gelişim ve öğrenme. In A. Ulusoy (Ed.), Sosyal öğrenme kuramı (pp. 206-243). Ankara: Anı Yayıncilik.

Kuzucu, Y. (2013). Küçükler için büyüklere çocuk ve ergen ruh sağlı̆̆g (3. Baskı). Ankara: Pegem Akademi Yayıncilik.

Lianos, P. G. (2015). Parenting and social competence in school: The role of preadolescents' personality traits. Journal of Adolescence, 41, 109-120. http://dx.doi.org/10.1016/j.adolescence.2015.03.006

Lin, Y. C., \& Yawkey, T. (2014). Parents' play beliefs and the relationship to children's social competence. Education, 135(1), 107-114. 
Magelinskaitè, Š., Kepalaitè, A., \& Legkauskas, V. (2014). Relationship between social competence, learning motivation, and school anxiety in primary school. Procedia-Social and Behavioral Sciences, 116, 2936-2940. http://dx.doi.org/10.1016/j.sbspro.2014.01.683

Malik, F., \& Shujja, S. (2013). Social competence and school systems as predictor of academic achievement in high and low achieving Pakistani school children. Journal of Behavioural Sciences, 23(1), 77-92.

Márquez, P. G. O., Martín, R. P., \& Brackett, M. A. (2006). Relating emotional intelligence to social competence and academic achievement in high school students. Psicothema, 18, 118-123.

Özbay, Y., \& Palanc1, M. (2001). Sosyal kaygı ölçeği: Geçerlik güvenirlik çalışması. VI. Ulusal Psikolojik Danışma ve Rehberlik Kongresinde sunulan bildiri, Ortadoğu Teknik Üniversitesi, Ankara.

Payne, R., \& Jahoda, A. (2004). The glasgow social self-efficacy scale a new scale for measuring social self-efficacy in people with intellectual disability. Clinical Psychology \& Psychotherapy, 11(4), 265-274. http://dx.doi.org/10.1002/cpp.412

Raffray, T., Bond, T. L. Y., \& Pelissolo, A. (2011). Correlates of insomnia in patients with social phobia: Role of $\begin{array}{llll}\text { depression and } & \text { anxiety. Psychiatry Research, }\end{array}$ http://dx.doi.org/10.1016/j.psychres.2011.03.004

Richards, J. M., Patel, N., Daniele-Zegarelli, T., MacPherson, L., Lejuez, C. W., \& Ernst, M. (2015). Social anxiety, acute social stress, and reward parameters interact to predict risky decision-making among adolescents. Journal of Anxiety Disorders, 29, 25-34. http://dx.doi.org/10.1016/j.janxdis.2014.10.001

Rose-Krasnor, L. (1997). The nature of social competence: A theoretical review. Social development, 6(1), 111-135. http://dx.doi.org/10.1111/j.1467-9507.1997.tb00097.x

Sarıçam, H., Akın, A., Akın, U., \& Çardak, M. (2013). Algılanan sosyal yetkinlik ölçeğinin Türkçeye uyarlanması: Geçerlik ve güvenirlik çalışması. The Journal of Academic Social Science Studies, 6(3), 591-600.

Seçer, İ. (2013). SPSS ve LISREL ile pratik veri analizi. Ankara: Anı Yayıncılık.

Sumi, K. (2011). Relations of social problem solving with interpersonal competence in Japanese students. Psychological Reports, 109(3), 976-982. http://dx.doi.org/10.2466/07.20.21.28.PR0.109.6.976-982

Ten-Dam, G., \& Volman, M. (2007). Educating for adulthood or for citizenship: Social competence as an educational goal. European Journal of Education, 42(2), 281-298. http://dx.doi.org/10.1111/j.1465-3435.2007.00295.x

Thomasson, P., \& Psouni, E. (2010). Social anxiety and related social impairment are linked to self-efficacy and dysfunctional coping. Scandinavian Journal of Psychology, 51, 171-178. http://dx.doi.org/10.1111/j.1467-9450.2009.00731.x

Torres, M. V. T., Cardelle-Elawar, M., Mena, M. J. B., \& Sanchez, A. M. M. (2003). Social background, gender and self-reported social competence in 11-and 12-year-old Andalusian children. Electronic Journal of Research in Educational Psychology, 1(2), 38-56.

Traş, Z., \& Arslan, E. (2013). Ergenlerde sosyal yetkinliğin, algılanan sosyal destek açısından incelenmesi. Ilkögretim Online, 12(4). 1133-1140.

Türe, H. (2009). Celal Bayar Üniversitesi Tıp Fakültesi öğrencilerinde sosyal kaygı düzeyini etkileyen faktörler (Uzmanlık tezi). Celal Bayar Üniversitesi Tıp Fakültesi, Manisa.

Usher, L. V., Burrows, C. A., Schwartz, C. B., \& Henderson, H. A. (2015). Social competence with an unfamiliar peer in children and adolescents with high functioning autism: Measurement and individual differences. Research in Autism Spectrum Disorders, 17, 25-39. http://dx.doi.org/10.1016/j.rasd.2015.05.005

Zhang, F., You, Z., Fan, C., Gao, C., Cohen, R., Hsueh, Y., \& Zhou, Z. (2014). Friendship quality, social preference, proximity prestige, and self-perceived social competence: Interactive influences on children's loneliness. Journal of School Psychology, 52(5), 511-526. http://dx.doi.org/10.1016/j.jsp.2014.06.001

Zsolnai, A. (2002). Relationship between children's social competence, learning motivation and school achievement. Educational psychology, 22(3), 317-329. http://dx.doi.org/10.1080/01443410220138548 


\section{Copyrights}

Copyright for this article is retained by the author(s), with first publication rights granted to the journal.

This is an open-access article distributed under the terms and conditions of the Creative Commons Attribution license (http://creativecommons.org/licenses/by/3.0/). 